\title{
Performance of cucumber varieties in soil infested with root-knot and reniform nematodes'
}

\author{
Rodrigo Echávez-Badel"
}

\begin{abstract}
The performance of three cucumber (Cucumis sativus) varieties was evaluated in two field experiments in a soil heavily infested with root-knot (Meloidogyne incognita) and reniform (Rotylenchulus reniformis) nematodes at the Isabela Agricultural Experiment Substation in 1987 and 1988. Contral treatments with carbofuran were included for comparison. Results of the combined analysis of variance indicated that the total production of varieties, $\mathrm{kg} / \mathrm{ha}$ and fruits/plots, was significantly higher $(P=0.05)$ in carbofuran-treated plots than in non-treated plats. Significant differences were also found for production between the hybrid Dasher II and Poinsett 76. It is important to note that three varieties tested showed resistance to root-knot and reniform nematodes.
\end{abstract}

\section{RESUMEN}

Reacción de variedades de pepinillo en suelo infestado con el nematodo nodulador de la raíz y el reniforme

En 1987 y 1988 en la Subestación Experimental de Isabela se evaluó el comportamiento de tres variedades de pepinillo (Cucumis sativus) en dos experimentos de campo en suelo altamente infestado con el nematodo nodulador de la raiz (Meloidogyne incognita) y el nematodo reniforme (Rotylenchulus reniformis). Se usó el tratamiento con carbofuran como testigo. Según los resultados y el análisis de varianza combinado, la producción total de las variedades probadas en kilogramos por hectárea y frutas por parcela aumentó significativamente $(P=0.05)$ cuando las parcelas se trataron con carbofuran. También se obtuvieron diferencias significativas entre la producción del híbrido Dasher II y la de Poinsett 76. Las tres variedades fueron resistentes al nematodo nodulador y al reniforme.

\section{INTRODUCTION}

The production of cucumber (Cucumis sativus) in Puerto Rico has been unstable during the last 10 years, fluctuating from 1,000 to $2,350 \mathrm{t}$ of fresh market fruits during growing seasons (3). In Puerto Rico yields of $45 \mathrm{t} / \mathrm{ha}$ with the pickling variety Sumter was reported by Mangual (13). One of the most important factors limiting cucumber production is

' Manuscript submitted to Editorial Board 19 April 1989.

2Assistant Plant Pathologist, Department of Crop Protection, Agricultural Experiment Station, University of Puerto Rico, Mayagüez Campus, Mayaguëz, P. R. 00709. The author thanks Raúl Cruz, Isabela Agricultural Experiment Substation, and José Soto, Laboratory of Nematology, U. P. R., Mayagüez Campus, for their cooperation in these experiments. 
the damage caused by plant parasitic nematodes. The association of Meloidogyne sp. and Rotylenchulus sp. with the production of cucurbits in Puerto Rico and the United States has been reported by various authors $(1,4,10,14)$. Dabaj et al. (6) and Fassuliotis (8) reported losses in cucumber caused by Meloidogyne incognita. Some nematicides have controlled $M$. incognita and $R$. reniformis populations in cucurbits $(1,11,12,14)$. The objective of these experiments was to evaluate the performance of cucumber varieties in soil naturally infested with the rootknot and the reniform nematodes.

\section{MATERIALS AND METHODS}

Two field experiments were conducted, one in 1987 and the other in 1988, at the agricultural exepriment substation of Isabela. The mean rainfall was $204 \mathrm{~mm}$ and $140 \mathrm{~mm}$ throughout the growing season in the 1987 and 1988 experiments, respectively. The soil was an Oxisol, Coto clay, with pH 6.3. The experimental site was selected on the basis of high nematode population levels prevalent in the area. Seed was treated with chloroneb $\left(\operatorname{Captan}^{\mathrm{R}}\right){ }^{3}{ }^{3}$ Three seeds were planted per hill $0.103 \mathrm{~m}$ apart in a single row $0.61 \mathrm{~m}$ long. Rows were spaced $1.83 \mathrm{~m}$ apart. Ten days after sowing, plants were thinned to 1 per $0.103 \mathrm{~m}$ within the row.

The treatments were three cucumber varieties: Geminis 7, Poinsett 76 , the hybrid Dasher II. The nematicide carbofuran (Furadan $\left.10 \mathrm{G}^{\mathrm{R}}\right)^{3}$ was applied to the soil at $18 \mathrm{~kg} / \mathrm{ha}$. The granular nematicide was applied by hand 15 days before planting in a $0.30-\mathrm{m}$ band and incorporated into the first 0.05 to $0.08 \mathrm{~m}$ of soil. Each treatment was replicated 5 times in a randomized complete block design with a factorial arrangement with varieties without nematicide and with carbofuran as control.

Planting, cultivation, fertilization, and control of weeds, insects, and fungi followed the general practice recommended by the Agricultural Experiment Station (2). Soil samples for nematode analysis (250 cc per plot) were taken $0.15 \mathrm{~m}$ deep before nematicide application and at harvest, approximately 3 months after planting. Nematodes were extracted from the soil by the Baermann funnel and Cobb's sieving methods (5). The following parameters were evaluated: yield, number of marketable and nonmarketable fruits per plot, gall index (GI) (15), M. incognita 2nd stage juveniles and $R$. reniformis population in the soil. All data pooled from 2 years' crops were analyzed by combined analysis of variance.

\section{RESULTS AND DISCUSSION}

Results of the combined analysis of variance for 2-year tests indicated that the total production of cucumber varieties, $\mathrm{kg} / \mathrm{ha}$ and fruits/plot,

${ }^{3} T$ Trade names in this publication are used only to provide specific information. Mention of a trade name does not constitute a warranty of equipment or materials by the Agricultural Experiment Station of the University of Puerto Rico, nor is this mention a statement of preference over other equipment or materials. 
was significantly higher in plants treated with carbofuran than in the other treatments (table 1). Acosta et al. (1) reported highest yield in cucumber plots treated with carbofuran, but these were not statistically different from untreated plots. Johnson and Harmon (11) and Littrell (12) increased yield of cucurbits with nematicides.

The mean ratios of final population to initial population ( $\mathrm{Pf} / \mathrm{Pi}$ ) were superior to those for $M$. incognita and $R$. reniformis (table 1 ). That is, the nematode population in the soil increased at harvesting time. Similar results have been reported by Greco and Thomanson (9). Apparently a great number of nematodes did not penetrate the roots and therefore were recovered from the soil. Population ratios were lower in treated plots than in nontreated (table 1). Populations of the reniform nematode were bigger than those of root-knot nematodes extracted from the soil. In contrast, Acosta et al. (1), Johnson and Harmon (11), and RodríguezKabana et al. (14), found a smaller nematode population at harvest with different applications of nematicides before and after planting.

In spite of the fact that the gall index was significantly lower in plants treated than in those untreated (table 1), the cucumber varieties showed little extensive gall response (table 1). The GI has been used as an indicator of plant damage associated with root-knot infection. An average of GI of 2 or fewer indicates "host resistance" and those greater than 2 indicate "host susceptibility" according to Taylor and Sasser (15). In our study, varieties without a nematicide showed slight swelling in the root system (table 1), which might be considered as "host resistance." Furthermore, no necrosis or hypersensitive reaction associated with larval invasion was observed. These results are similar to those in Fassuliotis' reports on resistance in Cucumber spp. (7), to reports by Taylor and Sasser on GI scale (15), and to those by Heald (10). Further histopathological studies are necessary for confirmation of these findings.

TABLE 1.-Production of cucumber varieties, gall index and population ratios (PfIPi) of Meloidogyne incognita and Rotylenchulus reniformis in non-treated and treated plots at Isabela, Puerto Rico

\begin{tabular}{|c|c|c|c|c|c|}
\hline \multirow[b]{2}{*}{ Theatments } & \multirow[b]{2}{*}{$\begin{array}{c}\text { Fruits/ } \\
\text { plot }\end{array}$} & \multirow[b]{2}{*}{$\begin{array}{l}\text { Yield } \\
\mathrm{kg} / \mathrm{ha}\end{array}$} & \multirow[b]{2}{*}{ Gall index' } & \multicolumn{2}{|c|}{$\begin{array}{l}\text { Population } \\
\text { ratios (PfrPi) }\end{array}$} \\
\hline & & & & $\begin{array}{l}\text { Root } \\
\text { knot }\end{array}$ & $\begin{array}{l}\text { Reniform } \\
\text { nematode }\end{array}$ \\
\hline Varieties & 33 & 66.034 & 2.4 & 3.0 & 3.7 \\
\hline $\begin{array}{l}\text { Varieties }+ \\
\text { Carbofuran } \\
\text { (Control) }\end{array}$ & $38^{* 1}$ & $80,101^{* * * 3}$ & $1.7^{* *: 3}$ & 2.7 & 2.4 \\
\hline
\end{tabular}

'Gall index: $0=$ non nodule, $1=1-2$ nodules, $2=3-10$ nodules, $3=11-30$ nodules, $4=31$ $100,5=$ more than 100 nodules.

"Mean ratios of final population ( $\mathrm{Pf}$ ) to initial population ( $\mathrm{Pi}$ ).

**: Significant, at $\mathrm{P}=0.05$ and $\mathrm{P}=0.01$, respectively. 
TABLE 2.-Production of cucumber varieties in two-year tests at Isabela, Puerto Rico

\begin{tabular}{lcl}
\hline Varieties & Fruits/Plol & yield (kg/ha) \\
\hline Dasher II & $40 \mathrm{a}^{\mathrm{l}}$ & $83,739 \mathrm{a}^{2}$ \\
Geminis 7 & $35 \mathrm{ab}$ & $73,091 \mathrm{ab}$ \\
Poinsett 76 & $32 \mathrm{~b}$ & $62,373 \mathrm{~b}$ \\
\hline
\end{tabular}

I and 2 Range separations were determined from the $\mathrm{LSD}, \mathrm{P}=0.05$ and $\mathrm{P}=0.01$, respectively. Values in columns followed by the same letter do not differ significantly.

Hybrid Dasher II was the highest-yielding variety, followed by Geminis 7 and Poinsett 76. Significant differences in fruits/plot and yield between Dasher II and Poinsett 76 were also obtained (table 2). Data in the following tabulation indicate that by 1988 the production of cucumber varieties was significantly higher $(\mathrm{P}=0.01)$ than in 1987.

$\begin{array}{ccc}\text { Year } & \text { Fruits/plot } & \text { Yield (kg/ha) } \\ 1987 & 25 & 47,726 \\ 1988 & 47^{* * 1} & 98,408^{* *-1}\end{array}$

This may have been due to the fact that average rainfall during the year was higher than in 1988. Many flowers fell; consequently, the production decreased.

Sigificant differences in yield for the interactions treatment $\times$ year and variety $x$ year were obtained. This demonstrates that treatments and varieties were influenced by changes in rainfall periods during the 1987 and 1988 growing seasons.

The results reported herein provide information on the good performance of these cucumber varieties in Puerto Rico. This information, combined with nematode control data, should enable farmers to make a more adequate use of carbofuran in cucumber plantings.

\section{LITERATURE CITED}

1. Acosta, N., C. Cruz and J. Negrón, 1986. Insect and nematode control in cucumber (Cucumis sativus) in Puerto Rico. J. Agric. Univ. P. R. 70 (1): 19-24.

2. Anonymous, 1979. Conjunto Tecnológico para la Produceión de Hortalizas. Publ. 102 (2d.). Esta. Exp. Agric., Univ. P. R., Rio Piedras, P. R.

3. Anonymous, 1986. Estadísticas Agrícolas. Departamento de Agricultura, Santurce, P. R.

4. Ayala A., and C. T. Ramírez, 1964. Host-range, distribution, and bibliography of the reniform nematode, Rotylenchulus reniformis with special reference to Puerto Rico. J. Agric. Univ. P. R. 48 (2): 140-61.

5. Christie, J. R. and V. G. Perry, 1951. Removing nematodes from soil. Proc. Helminthol. Soc. Wash. 18: 106-08.

6. Dabaj, J. R. and M. W. Khan, 1982. Root-knot nematodes on indoor cucumbers in Tripoli regions of Libian Yamahiriya. Plant Dis. 66 (9): 819-20.

7. Fassuliotis, G., 1970. Resistance of Cucumis spp. to the root-knot nematode, Meloidogyne incognita acrita. J. Nematol. 2 (2): 174-8.

${ }^{4}$ Significant difference $(\mathrm{P}=0.01)$ between 1987 and 1988 . 
8. — 1971. Susceptibility of Cucurbita spp. to the root-knot nematode, Meloidogyne incognita Pl. Dis. Rep. 55 (8): 666 (Abstr.).

9. Greco, N. and I. J. Thomanson, 1980. Effect of phenamiphos on Heterodera schachtii and Meloidogyne hapla. J. Nematol. 12: 91-6.

10. Heald, C. M., 1975. Pathogenicity and Histopathology of Rotylenchulus reniformis infecting cantaloup. J. Nematol. 7 (1): 150-2.

11. Johnson, A. W. and S. A. Harmon, 1974. Cantaloup yield and grade increased by chemical control of Meloidogyne incognita. Pl. Dis. Rep. 58: 746-9.

12. Littrell, R. H., 1983. Nematode control of vegetable with systemic nematicides. CRIS, Georgia Coastal Plain Exp. Stn., Tifton, GA. (Abstr.).

13. Mangual Crespo, G. 1982. Pickling cucumber (Cucumis satious) cultivar evaluation in northwestern Puerto Rico. J. Agric. Univ. P. R. 66 (3): 177-80.

14. Rodriguez-Kabana, R., B. Truelove, and P. S. King, 1977. A seed treatment method for control of plant parasitic nematodes on soybeans and cucumbers. Nematropica 7 (1): 5-6.

15. Taylor, A. L. and J. N. Sasser, 1978. Biology, identification and control of root-knot nematodes (Meloidogyne spp.). Coop. Publ. Dep. Plant Pathol., North Carolina State Univ. and US Agency Int. Dev. Raleigh, NC. 111 pp. 